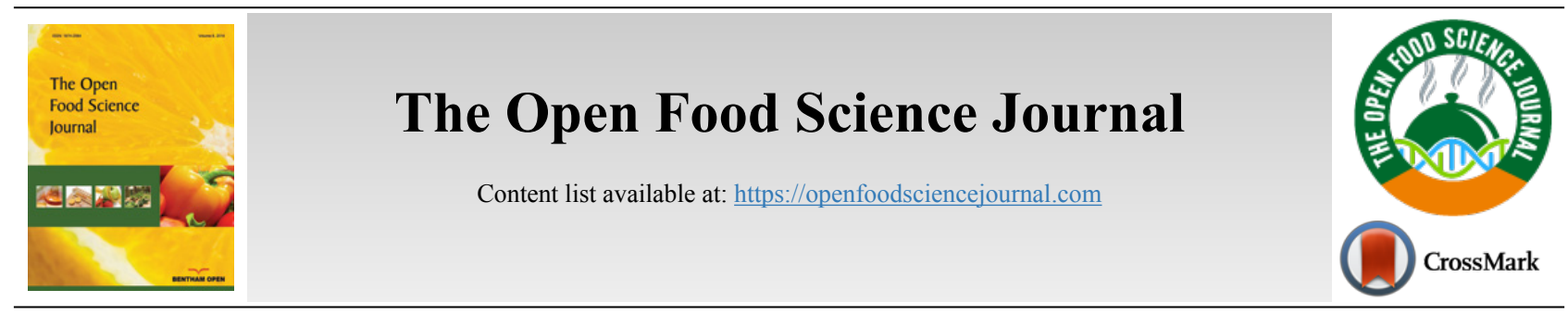

RESEARCH ARTICLE

\title{
Aqueous Enzymatic Extraction of Buriti (Mauritia Flexuosa) Oil: Yield and Antioxidant Compounds
}

\author{
Jezica P.P. Silva, Antonio M.C. Rodrigues and Luiza H.M. Silva* \\ Federal University of Pará (UFPA), Technology Institute (ITEC), Graduate Program in Food Science and Technology (PPGCTA), Belém, Pará, \\ Brazil
}

\begin{abstract}
:
Introduction:

Enzyme-assisted aqueous extraction is considered an emerging green technique that has been applied to different oilseeds.

Objective:

This study aimed to study the enzymatic aqueous extraction process of buriti oil using a central composite rotatable design (CCRD) combined with the response surface methodology aiming to obtain higher yield and antioxidant compounds in the oil.

Methods:

The study was carried out in two steps. The first assessed the efficiency of different enzymes (cellulase, pectinase, and protease) and the variables of greater influence in the extraction process, being conducted for each enzyme a CCRD design. The second step was carried out with the enzyme that showed the best performance on the extraction yield, changing the experimental bands of the variables that had greater significance in the first step, with the goal of broadening the spectrum of study. Were also evaluated in this step, total carotenoids, total phenolic compounds, and the antioxidant capacity of the oils extracted.

Results:

In the first experiment, cellulase gave the highest yield, while the most significant variables were temperature and time. For the second design, performed with cellulase, were defined as optimal operating conditions at $55{ }^{\circ} \mathrm{C}$ temperature, $2 \%$ enzyme concentration and 6 hours extraction. For these conditions, the yield obtained was $76.5 \%$, with total carotenoid concentration of 3,119.5 $\mu \mathrm{g} \beta$-carotene. $\mathrm{g}^{-1}$. Analysis of variance was performed and showed the significance of the regression and non-significance of the lack-of-fit $(\mathrm{p}<0.05)$. The coefficients of determination of the yield and carotenoid content were $95.6 \%$ and $94.5 \%$, respectively. The highest value of total phenolic compounds determined for buriti oil in this study was $254 \pm 5 \mu \mathrm{g} \mathrm{GAE} . \mathrm{g}^{-1}$ oil, while for the antioxidant capacity was $218.0 \pm 0.3 \mu \mathrm{mol}$ Trolox. $\mathrm{g}^{-1}$ oil.

Conclusion:

The enzymatic aqueous extraction process is viable for buriti oil and produced oils with high concentrations of antioxidant compounds.
\end{abstract}

Keywords: Enzymatic extraction, Yield, Experimental design, Buriti oil, Total carotenoids, Antioxidant compounds.

\begin{tabular}{l|l|l|l} 
Article History & Received: September 10, 2018 & Revised: December 05, 2018 & Accepted: December 17, 2018
\end{tabular}

\section{INTRODUCTION}

Buriti palm (Mauritia flexuosa Lf) belongs to the family Arecaceae and is widely distributed across the Amazon Forest in Brazil $[1,2]$. It grows in swamps and in seasonally flooded areas along rivers and forests [3]. Buriti has great ecological,

* Address correspondence to this author at the Federal University of Pará (UFPA), Technology Institute (ITEC), Graduate Program in Food Science and Technology (PPGCTA), Belém, Pará, Brazil; Tel: +55 (91) 32018988; E-mail: lhmeller@ufpa.br cultural, and economic value and is very important for the subsistence of the local population. Nearly all parts of the palm three, from the roots to the fruits, are useful for human needs and activities, such as diet, clothing and housing [4 - 6].

Buriti fruit has yellow pulp and peculiar flavor and is common in the diet of the riverine population, being used to make desserts, jams, ice cream, conserves, and wines [7 - 9]. Oil extraction from buriti attracts interest for the physical and chemical properties of the product [2], such as high contents of tocopherols and carotenoids, particularly $\beta$-carotene, which 
accounts for the reddish orange color of the oil [5, 10, 11].

Conventional oil extraction processes for oilseeds or fruit pulp involve mechanical and solvent extraction [12 - 15]. In face of environmental safety and risks to public health, the food industry is being required to employ alternatives to the organic solvents used in oil extraction, such as enzyme-assisted aqueous extraction, an emerging environmentally friendly technology $[14,16]$. This process has been widely applied to extract oil from a variety of fruits and seeds [14 - 27].

Enzymatic aqueous extraction employs enzymes that hydrolyze and break cell walls of the material, making the structure more permeable and further exposing the oil component $[28,29]$.

This study aimed to apply a CCRD to the enzymatic extraction process of buriti oil. The effects of different enzymes (cellulase, pectinase, and protease) and significant variables that impacted oil yield were investigated. In the first step, the enzyme was selected and the most significant variables determined. Next, a second CCRD was carried out with different ranges for the most significant variables to determine the optimal extraction conditions. Besides yield, total carotenoids, total phenolic compounds, and antioxidant capacity (ABTS method) of the oils extracted were assessed.

\section{MATERIALS AND METHODS}

\subsection{Raw Material}

The raw material used was buriti pulp and skin (mesocarp and epicarp), purchased at the Ver-o-Peso market in the city of Belém, PA, Brazil. The raw material was stored at $-10{ }^{\circ} \mathrm{C}$ in $1 \mathrm{~kg}$ packages until use.

\subsection{Enzymes}

The enzymes applied in the extraction process were Celluclast $^{\circledR} 1.5 \mathrm{~L}$ (cellulase) with $700{\mathrm{U} . \mathrm{g}^{-1} \text { EGU activity, Pectinex }}^{\circledR}$ Ultra SP-L (pectinase) with 3,800 U.g ${ }^{-1}$ PGNU activity, and Alcalase $^{\circledR}$ 2.4L FG (protease) with $2.4{\mathrm{U} . \mathrm{g}^{-1}}^{-1} \mathrm{AU}-\mathrm{A}$ activity and were kindly provided by the company Novozymes ${ }^{\circledR}$ (Bento Gonçalves, RS, Brazil).

\subsection{Total Lipid Content}

The total amount of buriti oil was determined using solvents [30]. Solvent extraction of buriti samples produced 9.4 $\pm 0.2 \mathrm{~g}$ oil. $100 \mathrm{~g}^{-1}$ (wet basis) of buriti pulp+skin, which was considered $100 \%$ yield to bench mark the oil produced by aqueous extraction.

\subsection{Enzymatic Aqueous Extraction Process}

The extraction process used $10 \mathrm{~g}$ of pulp+skin added with distilled water at a 1:1 ratio $(\mathrm{m} / \mathrm{v})$ in an Erlenmeyer flask. Next, the enzyme was added according to the concentration established in each assay. This mixture was placed in an orbital shaker at $150 \mathrm{rpm}$ under the temperature and time conditions defined for each assay. After incubation, the enzymes were inactivated at $75{ }^{\circ} \mathrm{C}$ for $5 \mathrm{~min}$ and the mixture was centrifuged for $20 \mathrm{~min}$ at $4,000 \mathrm{~g}$ to separate the oily phase.

Extraction yield was calculated as percentages according to Equation 1.

$$
\text { Yield }_{\text {oil }}=\frac{W o(g) / W p(g)}{W t(g / g)} \times 100
$$

Where: Wo is the mass of buriti oil obtained through enzymatic extraction $(\mathrm{g}), \mathrm{Wp}$ is the sample mass $(\mathrm{g})$, and $\mathrm{Wt}$ is the total mass of oil obtained through solvent extraction.

The study of the enzymatic extraction process of buriti oil was done in two steps: The first assessed the efficiency of the different enzymes in the extraction process through a $2^{3}$ full factorial experimental design with three replicates at the central point using a CCRD, with a total of 17 assays per enzyme studied (cellulase, pectinase, and protease). This aimed to assess the influence of the independent variables (enzyme concentration $([\mathrm{E}])$, reaction time $(\mathrm{t})$, and reaction temperature (T)) on oil yield.

Table 1 presents the coded and actual values of the variables in the enzymatic treatment of the first step of the extraction process.

After the enzyme that gave the best yield was defined, the second step of the enzymatic extraction process was performed using a CCRD combined with the Response Surface Methodology (RSM). The ranges of the independent variables ([E], $t$, and T) were changed according to the significance of the first CCRD. In addition, the speed of the orbital shaker was changed to $120 \mathrm{rpm}$ and the sample mass was five times greater. The optimal extraction conditions were assessed based on the yield and concentration of total carotenoids in the oil.

Table 2 presents the coded and actual values of the variables in the enzymatic treatment of the second step of the enzymatic extraction process.

Equation 2 is the overall equation for the CCRD.

Where $Y$ represents the response predicted and $\beta o, \beta i, \beta i i$, and $\beta i j$ are the regression coefficients of the variables for intercept, linear (L), quadratic $(\mathrm{Q})$, and interaction terms, respectively. $X i$ and $X j$ are the levels of the coded independent variables.

$$
y=\beta o+\sum_{i=1}^{k} \beta i X i+\sum_{i=1}^{k} \beta i i X i^{2}+\sum_{i>j}^{k} \beta i j X i X j(\mathrm{k}=\mathrm{n})
$$

\subsection{Antioxidant Compounds in Buriti Oil}

\subsubsection{Total Carotenoids}

Total carotenoid content was determined by scanning spectrophotometry according to the methodology described by Rodriguez Amaya [30]. The content was calculated based on absorption at the maximum absorption wavelength and absorbance value (A) of 2,592 in petroleum ether. The values were expressed as $\mu \mathrm{g} \beta$-carotene per gram of oil $\left(\mu \mathrm{g} \beta\right.$-carotene.g $\left.\mathrm{g}^{-1}\right)$.

\subsubsection{Total Phenolic Compounds}

The total concentration of phenolic compounds in the oil (1 $\mathrm{g}$ oil in $80 \%$ methanol) was quantified using the FolinCiocalteu reagent [32] with small changes. A $300 \mu \mathrm{L}$ aliquot of methanolic extract was mixed with $5 \mathrm{~mL}$ Folin-Ciocalteu reagent (10\% in distilled water). After $5 \mathrm{~min}, 4 \mathrm{~mL} \mathrm{Na} \mathrm{CO}_{3}$ ( $7.5 \%$ in distilled water) were added. The samples were incubated for $1 \mathrm{~h}$ at room temperature protected from light Absorbance was measured at $765 \mathrm{~nm}$. The standard curve was prepared with galic acid. The results were expressed as $\mathrm{mg}$ of gallic acid equivalent per $g$ of sample ( $\mu$ g GAE. $\left.g^{-1}\right)$. 
Table 1. Levels of variables for enzymatic treatment of different enzymes: selection of enzymes and most significant variables.

\begin{tabular}{|c|c|c|c|c|c|}
\hline Variables & $-\boldsymbol{\alpha}$ & $\mathbf{- 1}$ & $\mathbf{0}$ & $\mathbf{1}$ & $+\boldsymbol{\alpha}$ \\
\hline $\mathrm{T}\left({ }^{\circ} \mathrm{C}\right)$ & 28.18 & 35 & 45 & 55 & 61.82 \\
\hline$[\mathrm{E}](\% \mathrm{~m} / \mathrm{v})$ & 1.32 & 2 & 3 & 4 & 4.68 \\
\hline $\mathrm{t}(\mathrm{h})$ & 0.32 & 1 & 2 & 3 & 3.68 \\
\hline
\end{tabular}

T: extraction temperature $\left({ }^{\circ} \mathrm{C}\right)$; [E]: enzyme concentration in relation to fruit mass $(\% \mathrm{~m} / \mathrm{v})$; t: reaction time (h).

Table 2. Levels of variables for enzymatic treatment: optimization of the process.

\begin{tabular}{|c|c|c|c|c|c|}
\hline Variables & $\mathbf{- \alpha}$ & $\mathbf{- 1}$ & $\mathbf{0}$ & $\mathbf{1}$ & $\mathbf{+ \alpha}$ \\
\hline $\mathrm{T}\left({ }^{\circ} \mathrm{C}\right)$ & 41.60 & 45 & 50 & 55 & 58.40 \\
\hline$[\mathrm{E}](\% \mathrm{~m} / \mathrm{v})$ & 0.66 & 1 & 1,5 & 2 & 2.34 \\
\hline $\mathrm{t}(\mathrm{h})$ & 0.64 & 2 & 4 & 6 \\
\hline
\end{tabular}

T: extraction temperature $\left({ }^{\circ} \mathrm{C}\right)$; [E]: enzyme concentration in relation to fruit mass $(\% \mathrm{~m} / \mathrm{v})$; t: reaction time (h).

Table 3. Experimental matrix of the enzymatic aqueous extraction process for different enzymes.

\begin{tabular}{|c|c|c|c|c|c|c|}
\hline Assays & $\mathbf{T}\left({ }^{\circ} \mathrm{C}\right)$ & {$[E](\% \mathrm{~m} / \mathrm{v})$} & t (hours) & Cellulase Yield (\%) & Pectinase Yield (\%) & Protease Yield (\%) \\
\hline 1 & 35 & 2 & 1 & 51.1 & 53.6 & 41.3 \\
\hline 2 & 35 & 2 & 3 & 65.5 & 64.6 & 56.1 \\
\hline 3 & 35 & 4 & 1 & 60.1 & 55.6 & 45.2 \\
\hline 4 & 35 & 4 & 3 & 76.8 & 68.3 & 57.1 \\
\hline 5 & 55 & 2 & 1 & 57.8 & 52.8 & 58.0 \\
\hline 6 & 55 & 2 & 3 & 84.0 & 61.6 & 60.6 \\
\hline 7 & 55 & 4 & 1 & 86.4 & 53.4 & 68.5 \\
\hline 8 & 55 & 4 & 3 & 95.9 & 65.4 & 69.3 \\
\hline 9 & 28.18 & 3 & 2 & 65.1 & 65.5 & 53.2 \\
\hline 10 & 61.82 & 3 & 2 & 87.1 & 57.8 & 70.6 \\
\hline 11 & 45 & 1.32 & 2 & 77.5 & 67.8 & 62.9 \\
\hline 12 & 45 & 4.68 & 2 & 82.5 & 70.3 & 65.6 \\
\hline 13 & 45 & 3 & 0.32 & 66.7 & 52.3 & 56.6 \\
\hline 14 & 45 & 3 & 3.68 & 88.5 & 63.1 & 66.7 \\
\hline 15 & 45 & 3 & 2 & 63.9 & 58.63 & 57.16 \\
\hline 16 & 45 & 3 & 2 & 61.2 & 58.04 & 58.82 \\
\hline 17 & 45 & 3 & 2 & 60.8 & 56.94 & 56.54 \\
\hline
\end{tabular}

T: extraction temperature $\left({ }^{\circ} \mathrm{C}\right)$; [E]: enzyme concentration in relation to fruit mass $(\% \mathrm{~m} / \mathrm{v})$; t: reaction time (h).

\subsection{Antioxidant Capacity}

Antioxidant activity of buriti oil was quantified based on the ABTS radical method as described by Rufino et al. [33] with the modifications of Pellegrini et al. [34].

\subsection{Statistical Analysis}

The results were submitted to analysis of variance (ANOVA) and the response surface methodology using the software STATISTICA $8.0^{\circledR}$.

\section{RESULTS AND DISCUSSION}

Table 3 presents the results of the CCRD for the different enzymes studied. Assay 8 for cellulase obtained the highest oil extraction yield with $95.9 \%$ at $55^{\circ} \mathrm{C}$, [E] of $4 \%$, and time of 3 $\mathrm{h}$. The lowest extraction value was obtained in assay 1 for protease with $41.3 \%$ at $35^{\circ} \mathrm{C}$, [E] of $2 \%$, and time of $1 \mathrm{~h}$.

The quadratic model for maximum oil extraction yield, after the elimination of the statistically insignificant terms ( $P>$ 0.05), are represented in Equations 3, 4, and 5, respectively, for cellulase, pectinase, and protease.

$$
\begin{gathered}
\text { Yield }=62.4+15 \cdot 8 \cdot \mathrm{X} 1+7 \cdot(\mathrm{X} 1)^{2}+10 \cdot 1 \cdot \mathrm{X} 2+9 \cdot 8 \cdot(\mathrm{X} 2)^{2}+15 \cdot 2 \cdot \mathrm{X}_{3}+8 \cdot 1 \cdot(\mathrm{X} 3)^{2}+5 \cdot 1 \cdot \mathrm{X} 1 \cdot \mathrm{X} 2 \\
\text { Yield }=58 \cdot 1-3 \cdot 2 \cdot \mathrm{X} 1+2 \cdot 1 \cdot \mathrm{X} 2+6.3 \cdot \mathrm{X} 3+9 \cdot 2 \cdot(\mathrm{X} 3)^{2}
\end{gathered}
$$




$$
\text { Yield }=57.9+12.6 \cdot \mathrm{X} 1+4 \cdot 2 \cdot \mathrm{X} 2+6.9 \cdot \mathrm{X}_{3}-5.8 \cdot \mathrm{X} 1 . \mathrm{X} 3
$$

Where: $\mathrm{X} 1$ : temperature $\left({ }^{\circ} \mathrm{C}\right) ; \mathrm{X} 2$ : enzyme concentration (\%); X3: time (h).

The most significant effect in the extraction process with cellulase was temperature (L) followed by time (L), whose effects were positive and indicated a directly proportional relation with extraction yield. Oil yield from pumpkin seed (Cucurbita maxima) increased with temperature and the rate of reactions catalyzed by the enzymes [13]. According to Jiang et al. [21] and Santos and Ferrari [34], the breakdown of cell wall components can be increased by extending the incubation time, which, consequently, enhances oil extraction yield.

When pectinase was used, the most significant effect for the extraction process was time (L). Temperature (L) had a negative effect, i.e., higher temperatures led to lower yield. The same behavior was observed by Gai et al. [35] for oil extraction from Isatis indigotica seeds. According to those authors, higher temperatures inactivated the enzyme.

The most significant effect in the extraction process with protease was temperature (L), which had a positive effect, as well as time (L) and enzyme concentration (L).

Analysis of variance was applied to all responses Tables 4, $\mathbf{5}$ and $\mathbf{6}$ and showed the significance of the regression and nonsignificance of the lack-of-fit at 95\% confidence $(P<0.05)$. The $\mathrm{F}$ value calculated for the regression was higher than the $\mathrm{F}$ tabulated and $p$-value was lower than 0.05 . That shows the model defined by the regression is appropriate to represent the mechanism of the aqueous enzymatic process of oil extraction in the conditions studied.

Fig. (1) shows the response surfaces generated through the model proposed for the yield of cellulase, pectinase, and protease, respectively. These surfaces confirm the analysis of effects carried out previously and enable visualizing the variation of the response for each parameter studied.

According to the response surfaces for cellulase, yield increased with increases in temperature and time and the region from 3.7 to $4.68 \%$ of enzyme concentration also led to higher yield. Fig. (1a) shows that the highest yields were obtained between 53 and $61.82{ }^{\circ} \mathrm{C}$ and enzyme concentration of 3.7 to $4.68 \%$. In Fig. (1b), temperature from 50 to $61.82^{\circ} \mathrm{C}$ and time from 2.5 to $3.68 \mathrm{~h}$ had the highest yields. In Fig. (1c), time from 2.7 to $3.68 \mathrm{~h}$ and enzyme concentration from 3.5 to $4.68 \%$ produced the best yields.

An analysis of Fig. (1) for pectinase showed that the parameters with the greatest impact on yield are time and enzyme concentration. Temperature, however, has inverse effect on yield, i.e., the higher the temperature, the lower the yield for the same enzyme concentration. In addition, a decrease in temperature and enzyme conce-ntrations below $1.5 \%$ and above $4.4 \%$ with a process time of $2.8 \mathrm{~h}$ resulted in the highest yield.

The response surfaces for protease showed that the parameter with the greatest impact on yield was temperature. Yields below $60 \%$ were obtained at temperatures below $50{ }^{\circ} \mathrm{C}$ for any enzyme concentration and times under $2.5 \mathrm{~h}$. The highest yields were obtained at over $52{ }^{\circ} \mathrm{C}$, enzyme concentration over $2.8 \%$, and time over $3.4 \mathrm{~h}$.

Cellulase was chosen for the second step of the extraction process since it obtained the highest oil yield. To allow for the analysis of the antioxidant compounds in the oils extracted, the extraction scale had to be increased for the second step of the CCRD, besides decreasing shaker rotation to prevent the formation of emulsion verified. According to Yang et al. [36], oil extracted by aqueous extraction commonly emulsifies, which can be prevented by adjusting shaking.

Table 4. Analysis of variance of yield using cellulase.

\begin{tabular}{|c|c|c|c|c|c|c|}
\hline ANOVA & Sum of squares & Degrees of freedom & Mean square & $\mathbf{F}_{\text {cal }}$ & $\mathbf{F}_{\text {tab }}$ & P \\
\hline Regression* & $2,627.8$ & 7 & 375.4 & 20.5 & 3.3 & 0.0163 \\
\hline Residue & 165.0 & 9 & 18.3 & - & - & - \\
\hline Lack-of-fit & 370.4 & 7 & 52.7 & 18.1 & 19.3 & 0.0534 \\
\hline Pure error & 5.8 & 2 & 2.9 & - & - & - \\
\hline Total & $2,792.8$ & 16 & - & - & - & - \\
\hline
\end{tabular}

*Significant effects at $5 \%$ significance. $\mathrm{R}^{2}=86.53 \%$.

Table 5. Analysis of variance of yield using pectinase.

\begin{tabular}{|c|c|c|c|c|c|c|}
\hline ANOVA & Sum of squares & Degrees of freedom & Mean square & $\mathbf{F}_{\text {cal }}$ & $\mathbf{F}_{\text {tab }}$ & P \\
\hline Regression* & 472.9 & 4 & 118.2 & 16.0 & 3.3 & 0.0185 \\
\hline Residue & 88.4 & 12 & 7.4 & - & - & - \\
\hline Lack-of-fit & 86.9 & 10 & 8.7 & 11.7 & 19.4 & 0.0811 \\
\hline Pure error & 1.5 & 2 & 0.7 & - & - & - \\
\hline Total & 561.3 & 16 & - & - & - & - \\
\hline
\end{tabular}

*Significant effects at 5\% significance. $\mathrm{R}^{2}=84.25 \%$.

Table 6. Analysis of variance of yield using protease.

\begin{tabular}{|c|c|c|c|c|c|c|}
\hline ANOVA & Sum of squares & Degrees of freedom & Mean square & $\mathbf{F}_{\text {cal }}$ & $\mathbf{F}_{\text {tab }}$ & $\mathbf{P}$ \\
\hline Regression* & 856.1 & 5 & 171.2 & 11.8 & 3.2 & 0.0207 \\
\hline
\end{tabular}




\begin{tabular}{|c|c|c|c|c|c|c|}
\hline ANOVA & Sum of squares & Degrees of freedom & Mean square & $\mathbf{F}_{\text {cal }}$ & $\mathbf{F}_{\text {tab }}$ & $\mathbf{P}$ \\
\hline Residue & 159.5 & 11 & 14.5 & - & - & - \\
\hline Lack-of-fit & 156.7 & 9 & 17.4 & 12.5 & 19.4 & 0.0729 \\
\hline Pure error & 2.8 & 2 & 1.4 & - & - & - \\
\hline Total & 1015.6 & 16 & - & - & - & - \\
\hline
\end{tabular}

*Significant effects at $5 \%$ significance. $\mathrm{R}^{2}=84.30 \%$.

Table 7 presents the experimental results of the CCRD as a function of yield and total carotenoids of buriti oil. The results showed that the best conditions for oil recovery and highest total carotenoid concentration were found in assay 8 at $76.5 \%$ of the total oil content of buriti pulp+skin and concentration of $3,119.5 \mu \mathrm{g} \beta$-carotene. $\mathrm{g}^{-1}$ oil at $55^{\circ} \mathrm{C}$, [E] of $2 \%$, and time of $6 \mathrm{~h}$.

The yields of the oils obtained through enzymatic extraction are equivalent to or higher than that from the conventional method of pressing, whose maximum yield is around $80 \%$ of the total oil in the seed [12]. The yield is lower compared to solvent extraction (above 99\% oil extraction), however, oil quality decreases when that methodology is used $[12,37]$. That makes enzymatic aqueous extraction a promising alternative since the oils extracted have higher quality than those extracted by traditional methods [18, 27, 38 - 40].

The quadratic model for maximum oil extraction yield and total carotenoids, after the elimination of the statistically insignificant terms $(P>0.05)$, are repres-ented in Equations 6 and 7 , respectively.
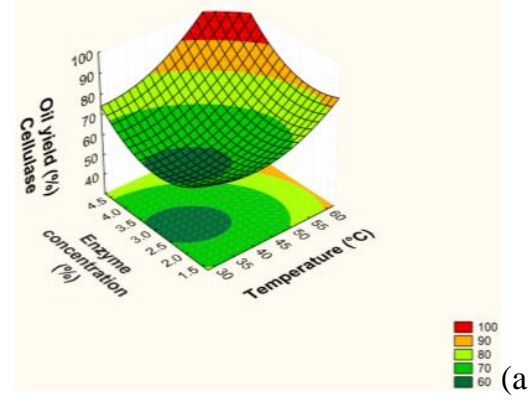

(a)
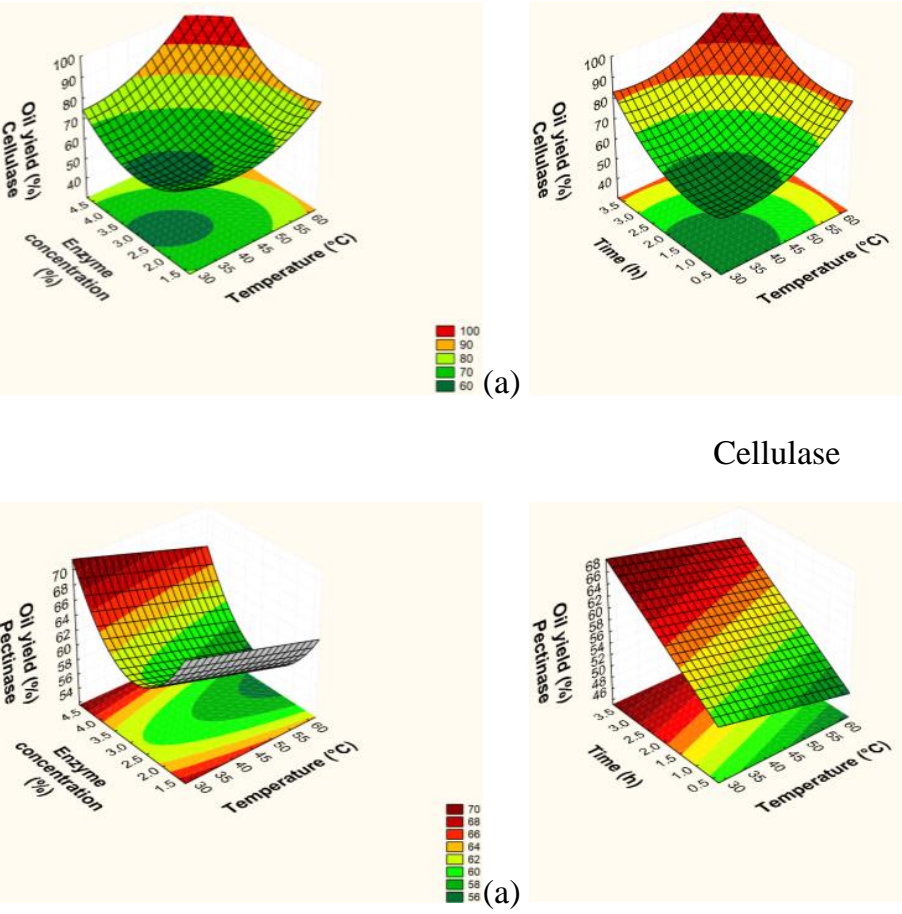

Pectinase
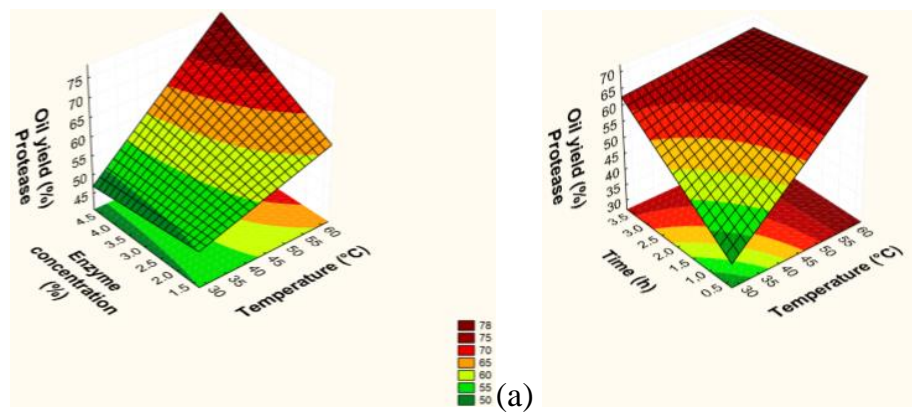

Protease

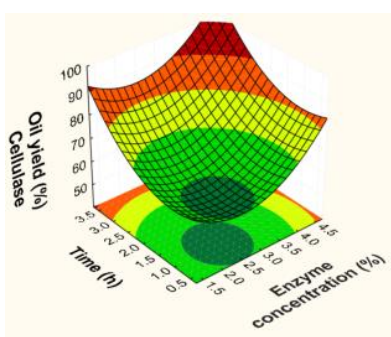

(b)

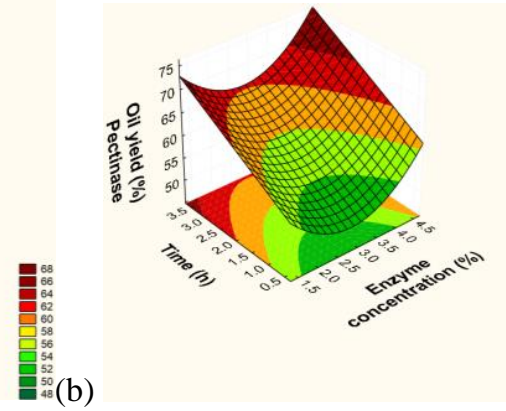

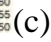
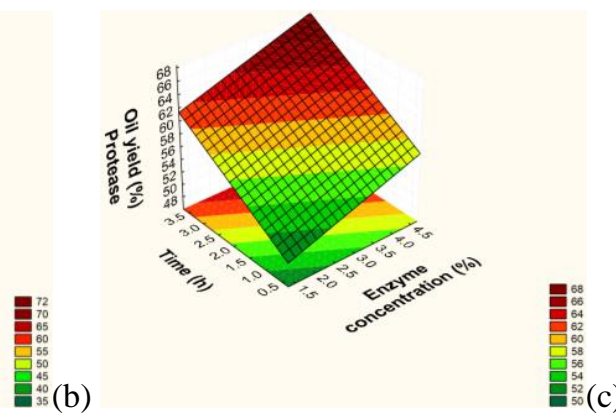

Fig. (1). Response surface for effects of (a) enzyme concentration with temperature; (b) time with temperature; and (c) time with enzyme concentration for oil extraction yield using cellulase, pectinase, and protease. 
Total carotenoids $=1,970 \cdot 2+422 \cdot 7 \cdot \mathrm{X} 1+601 \cdot 9 \cdot \mathrm{X} 2+143 \cdot 8 \cdot(\mathrm{X} 2)^{2}+194 \cdot 4 \cdot \mathrm{X}_{3}+215 \cdot 2 \cdot(\mathrm{X} 3)^{2}$

$+479.7 . \mathrm{X} 1 . \mathrm{X} 2$

Where: $\mathrm{X} 1$ : temperature $\left({ }^{\circ} \mathrm{C}\right)$; X2: enzyme concentration (\%); X3: time (h).

The most significant effect for the extraction process was time (L). Liu, Jiang and Li [41] observed that increases in time or temperature increased oil extraction from watermelon seeds.

Analysis of variance, presented in Table 8, shows the model is significant. $\mathrm{F}$ calculated for yield $\left(\mathrm{F}_{\text {cal }}=93.1>\mathrm{F}_{\text {tab }}=\right.$ 3.4 ) is approximately 27 higher than $\mathrm{F}$ tabulated and $P<$ 0.0196 shows this regression was statistically significant at $95 \%$ confidence. In addition, the $\mathrm{R}^{2}$ value (multiple correlation coefficient) of the regression equation obtained was 0.9558 (value $>0.75$ indicates aptitude of the model), which means the model can explain $95.6 \%$ of the variation in response. ANOVA for total carotenoids Table 9 showed significance of the regression and non-significance of the lack-of-fit at $95 \%$ confidence $(P<0.05)$, while $\mathrm{R}^{2}$ was 0.9450 , indicating the model explained $94.5 \%$ of the variation in experimental data.

The response surfaces from the model proposed are presented in Fig. (2a, $2 \mathbf{b}$ and $\mathbf{2 c}$ ) for yield and (2d), (2e), and (2f) for total carotenoids.

According to the response surfaces Fig. (2), yield increased with time. In Fig. (2a), the range with the highest yield is for enzyme concentration between 1.50 and $2.34 \%$, temperature from 47 to $57{ }^{\circ} \mathrm{C}$, and time of $4 \mathrm{~h}$. In Fig. (2b), with temperatures above $45^{\circ} \mathrm{C}$ and time over $5.5 \mathrm{~h}$, yields were around $75 \%$. Yields around $80 \%$ were obtained with time above $4.7 \mathrm{~h}$, enzyme concentration above $1.2 \%$, and temperature of $50{ }^{\circ} \mathrm{C}$, shown in Fig. (2c).

An increase in enzyme concentration for the same temperature and time resulted in higher yield. Gai et al. [35] extracted oil from Isatis indigotica seeds and observed that higher enzyme concentration favored oil extraction and higher yield. Najafian et al. [19], Teixeira et al. [27], and Santos and Ferrari [34] observed the same behavior in the extraction of oil from olives, palm, and soybean, respectively.

An analysis of Fig. (2), shows the parameters that had the greatest impact on total carotenoids were enzyme concentration and temperature. The highest total carotenoid concentration in buriti oil was obtained using temperature between 52 and 58.41 ${ }^{\circ} \mathrm{C}$, enzyme conce-ntration between 1.8 and $2.34 \%$, and time between 5 and $7.36 \mathrm{~h}$.

The assays of the enzymatic process obtained higher total carotenoid values than those found in the literature $[3,4,42$ 45].

The mean values of total phenolic compounds for the buriti oil samples are presented in Table 7. Assay 14, with $254 \pm 5 \mu \mathrm{g}$ GAE. $\mathrm{g}^{-1}$ oil, obtained the highest amount of phenolic compounds using temperature of $50^{\circ} \mathrm{C}$, enzyme concentration of $1.5 \%$ and time of $7.36 \mathrm{~h}$. Time impacted total phenolic concentration, i.e., the longer the extraction, the higher the phenolic compound concentration.

Ribeiro [46] characterized buriti oil and found $303 \mu \mathrm{g}$ GAE. $\mathrm{g}^{-1}$ oil for phenolic compounds. Jiao et al. [13] used a blend of enzymes (cellulase, pectinase, and proteinase) for enzymatic aqueous extraction of oil from pumpkin seeds and reported that the total phenolic compounds extracted by this method (128.8 $\mu$ g GAE.g ${ }^{-1}$ oil) were higher than through soxhlet extraction $\left(73.3 \mu \mathrm{g}\right.$ GAE.g ${ }^{-1}$ oil).

The means and standard deviations for antioxidant capacity data through ABTS $\bullet+$ are presented in Table 7. Assay 17 obtained the highest antioxidant potential with $218.0 \pm 0.3$ $\mu$ mol Trolox. $g^{-1}$ oil at temperature of $50{ }^{\circ} \mathrm{C}$, enzyme concentration of $1.5 \%$, and time of $4 \mathrm{~h}$.

Increasing temperature from $45{ }^{\circ} \mathrm{C}$ to $55{ }^{\circ} \mathrm{C}$ increased antioxidant capacity, which was also observed when time was extended from 2 to $6 \mathrm{~h}$. Decreasing enzyme conce-ntration from 1 to $2 \%$ decreased antioxidant capacity.

Luzia [47] determined the antioxidant capacity of oils from seeds of seven species of the Brazilian Cerrado biome, among which buriti seed oil had an antioxidant potential of $0.9 \mu \mathrm{mol}$ Trolox.g ${ }^{-1}$ oil.

Table 7. Experimental matrix of the CCRD as a function of yield, total carotenoids, total phenolic compounds, and antioxidant activity of buriti oil.

\begin{tabular}{|c|c|c|c|c|c|c|c|}
\hline Assays & $\mathbf{T}\left({ }^{\circ} \mathbf{C}\right)$ & {$[\mathbf{E}](\mathbf{\%})$} & $\mathbf{t}($ hours) & Yield (\%) & $\begin{array}{c}\text { Total carotenoids }(\boldsymbol{\mu g} \boldsymbol{\beta}- \\
\left.\text { carotene.g }^{\mathbf{1}}\right)\end{array}$ & $\begin{array}{c}\text { Total phenolic compounds }(\boldsymbol{\mu g} \\
\left.\text { GAE.g oil }^{-1}\right)\end{array}$ & ABTS $\left(\boldsymbol{\mu m o l ~ T r o l o x . g ~ o i l ~}^{-1}\right)$ \\
\hline 1 & 45 & 1 & 2 & 36.7 & $1,733.5$ & $162 \pm 4$ & $165 \pm 2$ \\
\hline 2 & 45 & 1 & 6 & 54.8 & $1,875.0$ & $217 \pm 4$ & $179 \pm 2$ \\
\hline 3 & 45 & 2 & 2 & 44.3 & $1,956.0$ & $198 \pm 6$. & $164 \pm 3$ \\
\hline 4 & 45 & 2 & 6 & 71.7 & $2,105.2$ & $216 \pm 8$ & $189 \pm 3$ \\
\hline 5 & 55 & 1 & 2 & 46.5 & $1,784.3$ & $206 \pm 6$ & $187 \pm 4$ \\
\hline 6 & 55 & 1 & 6 & 67.6 & $1,949.5$ & $214 \pm 4$ & $203 \pm 1$ \\
\hline 7 & 55 & 2 & 2 & 50.9 & $2,986.0$ & $187 \pm 2$ & $175.3 \pm 0.2$ \\
\hline 8 & 55 & 2 & 6 & 76.5 & $3,119.5$ & $208 \pm 5$ & $185.6 \pm 0.2$ \\
\hline 9 & 41.59 & 2 & 4 & 54.5 & $1,754.7$ & $115 \pm 6$ & $174 \pm 4$ \\
\hline
\end{tabular}




\begin{tabular}{|c|c|c|c|c|c|c|c|}
\hline Assays & $\mathbf{T}\left({ }^{\circ} \mathbf{C}\right)$ & {$[\mathrm{E}](\%)$} & thours) & Yield (\%) & $\begin{array}{c}\text { Total carotenoids }(\mu \mathrm{g} \beta- \\
\left.\text { carotene. } \mathrm{g}^{1}\right)\end{array}$ & $\begin{array}{c}\text { Total phenolic compounds ( } \mu \mathrm{g} \\
\left.\text { GAE.g oil }{ }^{-1}\right)\end{array}$ & ABTS ( $\mu$ mol Trolox.g oil $\left.{ }^{-1}\right)$ \\
\hline 10 & 58.41 & 2 & 4 & 58.4 & $2,181.1$ & $175 \pm 1$ & $178 \pm 2$ \\
\hline 11 & 50 & 0.66 & 4 & 50.5 & $1,753.8$ & $165 \pm 4$ & $178 \pm 3$ \\
\hline 12 & 50 & 2.34 & 4 & 65.5 & $2,518.4$ & $160 \pm 2$ & $177 \pm 3$ \\
\hline 13 & 50 & 1.5 & 0.64 & 37.9 & $2,017.5$ & $208 \pm 4$ & $177 \pm 3$ \\
\hline 14 & 50 & 1.5 & 7.36 & 74.9 & $2,456.5$ & $254 \pm 5$ & $204 \pm 3$ \\
\hline 15 & 50 & 1.5 & 4 & 64.8 & $1,999.1$ & $231 \pm 5$ & $214 \pm 2$ \\
\hline 16 & 50 & 1.5 & 4 & 62.8 & $1,932.2$ & $238 \pm 4$ & $215 \pm 2$ \\
\hline 17 & 50 & 1.5 & 4 & 64.1 & $1,992.2$ & $227 \pm 7$ & $218.0 \pm 0.3$ \\
\hline
\end{tabular}

T: extraction temperature $\left({ }^{\circ} \mathrm{C}\right)$; [E]: enzyme concentration in relation to fruit mass $(\% \mathrm{~m} / \mathrm{v})$; t: reaction time $(\mathrm{h})$.

Table 8. Analysis of variance of yield.

\begin{tabular}{|c|c|c|c|c|c|c|}
\hline ANOVA & Sum of squares & Degrees of freedom & Mean square & $\mathbf{F}_{\text {cal }}$ & $\mathbf{F}_{\text {tab }}$ & P \\
\hline Regression* & $2,367.4$ & 8 & 295.9 & 93.1 & 3.4 & 0.0196 \\
\hline Residue & 25.4 & 8 & 3.2 & - & - & - \\
\hline Lack-of-fit & 103.9 & 6 & 17.3 & 17.7 & 19.3 & 0.0546 \\
\hline Pure error & 2.0 & 2 & 1.0 & - & - & - \\
\hline Total & $2,392.8$ & 16 & - & - & - & - \\
\hline
\end{tabular}

*Significant effects at $5 \%$ significance.
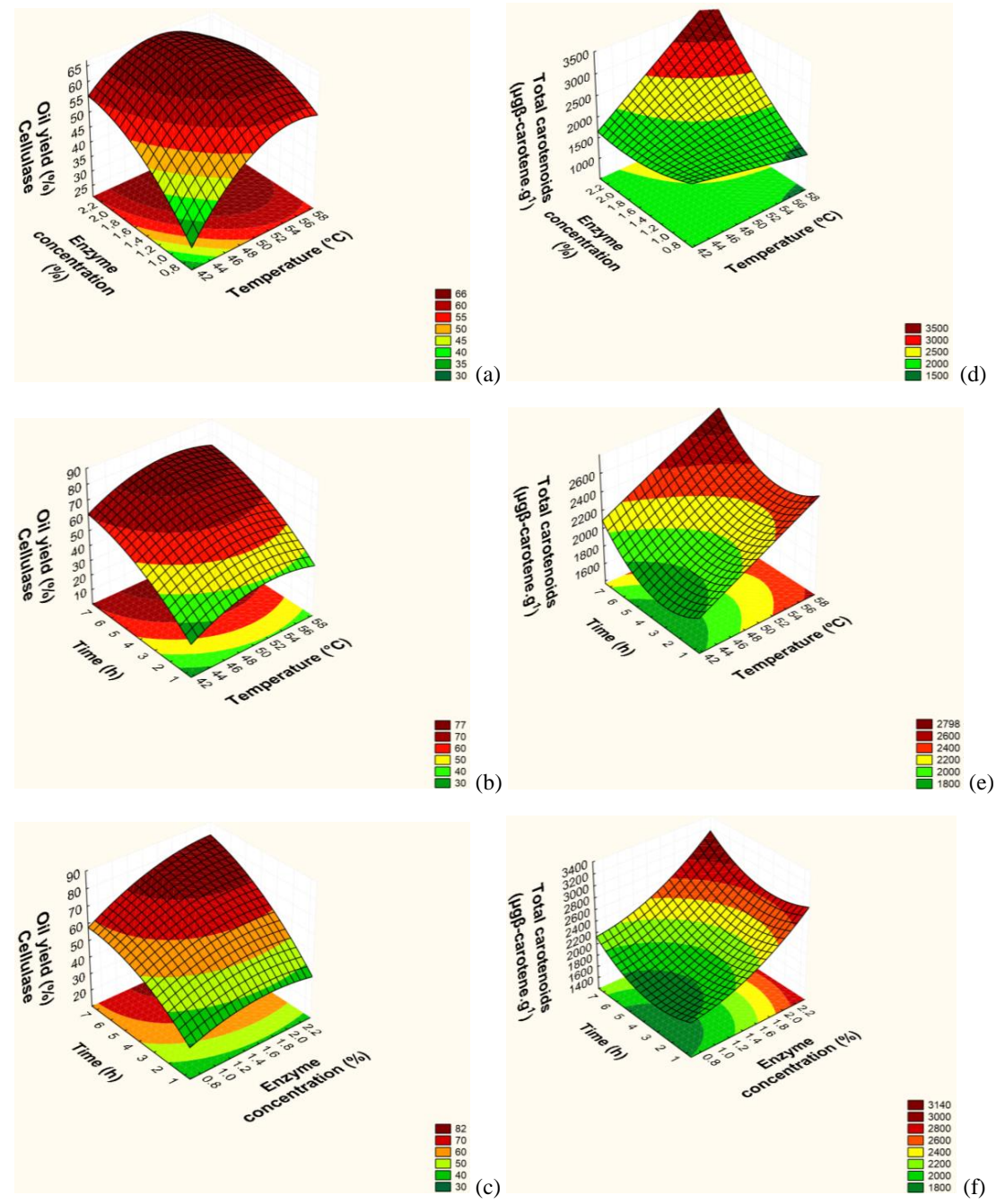

Fig. (2). Response surface for effect of (a, d) enzyme concentration with temperature; (b, e) time with temperature; (c, f) time with enzyme concentration for yield and total carotenoids. 
Table 9. Analysis of variance of total carotenoids.

\begin{tabular}{|c|c|c|c|c|c|c|}
\hline ANOVA & Sum of squares & Degrees of freedom & Mean square & $\mathbf{F}_{\text {cal }}$ & $\mathbf{F}_{\text {tab }}$ & P \\
\hline Regression* & $2,627,366$ & 6 & $437,894.3$ & 36.7 & 3.2 & 0.0196 \\
\hline Residue & 119,378 & 10 & $11,937.8$ & - & - & - \\
\hline Lack-of-fit & 148,329 & 8 & $18,541.1$ & 13.7 & 19.4 & 0.0546 \\
\hline Pure error & 2,708 & 2 & 1,354 & - & - & - \\
\hline Total & $2,746,744$ & 16 & - & - & - & - \\
\hline
\end{tabular}

*Significant effects at $5 \%$ significance.

\section{CONCLUSION}

Enzymatic aqueous extraction led to good buriti oil extraction results, with higher or equivalent yields compared to pressing extraction, but less than solvent extraction. Among the studied enzymes, the cellulase presented the best extraction yield. Increasing the temperature, time and concentration of enzyme favored oil yield. The most significant variable for the process was the time. The extracted oils obtained with a high concentration of total carotenoids, total phenolic compounds and antioxidant capacity, presented better nutritional quality than those extracted by traditional methods. This methodology is viable and environmen-tally friendly, does not produce volatile organic compounds as atmospheric pollutants, and its byproducts such as protein and fiber have high quality functional properties free of toxins, thus they can be applied to other processes.

\section{ETHICS APPROVAL AND CONSENT TO PARTICIPATE}

Not applicable.

\section{HUMAN AND ANIMAL RIGHTS}

No animals/humans were used for studies that are the basis of this research.

\section{CONSENT FOR PUBLICATION}

Not applicable.

\section{CONFLICT OF INTEREST}

The authors declare no conflict of interest, financial or otherwise.

\section{ACKNOWLEDGEMENTS}

The authors thank PROPESP/UFPA (Provost's Office for Research and Graduate Studies of the Federal University of Pará), CNPq (National Research and Development Council, processes 308021/2015-0 and 477013/2013-282 9), and CAPES (Coordination for the Improvement of Higher Education Personnel).

\section{REFERENCES}

[1] Delgado-Vargas F, Jiménez AR, Paredes-López O. Natural pigments: Carotenoids, anthocyanins, and betalains-characteristics, biosynthesis, processing, and stability. Crit Rev Food Sci Nutr 2000; 40(3): 173-289.

[http://dx.doi.org/10.1080/10408690091189257] [PMID: 10850526]

[2] Melo WS, Pena RS, Rodrigues AMC, Silva LHM. Hygroscopic behavior of buriti (Mauritia flexuosa) fruit. Food Sci Technol (Campinas) 2011; 31(4): 935-40.

[http://dx.doi.org/10.1590/S0101-20612011000400017]

[3] Cunha MAE, Neves RF, Souza JNS, et al. Supercritical adsorption of buriti oil (Mauritia flexuosa art.) in $\gamma$-alumina: A methodology for the enriching of anti-oxidants. J Supercrit Fluids 2012; 66: 181-91. [http://dx.doi.org/10.1016/j.supflu.2011.10.021]

[4] Darnet SH, Silva LHM, Rodrigues AMC, Lins RT. Nutritional composition, fatty acid na toopherol contentes of buriti (Mauritia flexuosa) and patawa (Oenocarpus bataua) fruit pulp from the amazona region. Ciênc Tenol Aliment 2011; 31(2): 488-91.

[http://dx.doi.org/10.1590/S0101-20612011000200032]

[5] Bataglion GA, Silva FMA, Eberlin MN, Koolen HHF. Simultaneous quantification of phenolic compounds in buriti fruit (Mauritia flexuosa L.f.) by ultra-high performance liquid chromatography coupled to tandem mass spectrometry. Food Res Int 2014; 66: 396-400. [http://dx.doi.org/10.1016/j.foodres.2014.09.035]

[6] Rull V, Montoya E. Mauritia flexuosa palm swamp communities: natural or human-made? A palynological study of the Gran Sabana region (northern South America) within a neotropical context. Quat Sci Rev 2014; 99: 17-33.

[http://dx.doi.org/10.1016/j.quascirev.2014.06.007]

[7] Lorenzi H, Bacher LB, Lacerda MTC, Santori SF. Frutas brasileiras e exóticas cultivadas. São Paulo: Instituto Plantarum de Estudos de Flora Ltda 2006; p. 377

[8] Silva JM, Coelho MJ, Lima KSC, et al. Evaluation of carotenoid contents irradiated Buriti (Mauritia flexuosa, L.). International Nuclear Atlantic Conference. 49-54.

[9] Cândido TL, Silva MR, Agostini-Costa TS. Bioactive compounds and antioxidant capacity of buriti (Mauritia flexuosa L.f.) from the Cerrado and Amazon biomes. Food Chem 2015; 177: 313-9.

[http://dx.doi.org/10.1016/j.foodchem.2015.01.041] [PMID: 25660 891]

[10] Durães JA, Drummond AL, Pimentel TAPF, Murta MM, Moreira SGC, Sales MJA. Thermal and structural behavior of buriti oil/ poly (methyl methacrylate) and buriti oil/ polystyrene materials. J Therm Anal Calorim 2008; 92(2): 529-34.

[http://dx.doi.org/10.1007/s10973-007-8564-z]

[11] Manhães LRT, Sabaa-Srur AUO. Centesimal composition and bioactive compounds in fruits of buriti collected in Pará. Food Sci Technol (Campinas) 2011; 31(4): 856-63

[http://dx.doi.org/10.1590/S0101-20612011000400005]

[12] Willwms P, Kuipers NJM, Haan AB. Hydraulic pressing of oiuseeds: Experimental determination and modeling of yield and pressing rates. J Food Eng 2008; 89: 8-16.

[http://dx.doi.org/10.1016/j.jfoodeng.2008.03.023]

[13] Jiao J, Li ZG, Gai QY, et al. Microwave-assisted aqueous enzymatic extraction of oil from pumpkin seeds and evaluation of its physicochemical properties, fatty acid compositions and antioxidant activities. Food Chem 2014; 147: 17-24.

[http://dx.doi.org/10.1016/j.foodchem.2013.09.079] [PMID: 24206 680]

[14] Assanvo EF, Kalita M, Saikia M, Baruah SD. Aqueous extraction of Ricinodendron heudelotii oil and directminiemulsion polymerization of the oil-in-water fraction. Ind Crops Prod 2016; 81: 30-7.

[http://dx.doi.org/10.1016/j.indcrop.2015.11.048]

[15] Ribeiro SAO, Nicacio AE, Zanqui AB, et al. Improvements in the quality of sesame oil obtained by a green extraction method using enzymes. Food Sci Technol (Campinas) 2016; 65: 464-70.

[16] Pengfei L, Wenbin Z, Xin H, et al. Demulsification of oil-rich emulsion and characterization of protein hydrolysates from peanut cream emulsion of aqueous extraction processing. J Food Eng 2017; 204: 64-72.

[http://dx.doi.org/10.1016/j.jfoodeng.2017.02.009]

[17] Latif S, Diosady LL, Anwar F. Enzyme-assisted aqueous extraction of oil and protein from canola (Brassica napus L.) seeds. Eur J Lipid Sci Technol 2008; 110: 887-92.

[http://dx.doi.org/10.1002/ejlt.200700319]

[18] Nyam KL, Tan CP, Lai OM, Long K, Man YBC. Enzyme-assisted 
aqueous extraction of Kalahari melon seed oil: Optimization using response surface methodology. J Am Oil Chem Soc 2009; 86: $1235-40$.

[http://dx.doi.org/10.1007/s11746-009-1462-8]

[19] Najafian L, Ghodsvali A, Khodaparast MHH, Diosady LL. Aqueous extraction of virgin olive oil using industrial enzymes. Food Res Int 2009; 42: 171-5

[http://dx.doi.org/10.1016/j.foodres.2008.10.002]

[20] Passos CP, Yilmaz S, Silva CM, Coimbra MA. Enhancement of grape seed oil extraction using a cell wall degrading enzyme cocktail. Food Chem 2009; 115: 48-53.

[http://dx.doi.org/10.1016/j.foodchem.2008.11.064]

[21] Jiang L, Hua D, Wang Z, Xu S. Aqueous enzymatic extraction of peanut oil and protein hydrolysates. Food Bioprod Process 2010; 88: 233-8.

[http://dx.doi.org/10.1016/j.fbp.2009.08.002]

[22] Towa LT, Kapchie VN, Hauck C, Murphy PA. Enzyme-assisted aqueous extraction of oil from isolated oleo somes of soybean flour. $\mathrm{J}$ Am Oil Chem Soc 2010; 87: 347-54.

[http://dx.doi.org/10.1007/s11746-009-1503-3]

[23] Latif S, Anwar F. Aqueous enzymatic sesame oil and protein extraction. Food Chem 2011; 125: 679-84

[http://dx.doi.org/10.1016/j.foodchem.2010.09.064]

[24] Wang L, Xu Y, Yang Y, Sun X. Aqueous enzymatic extraction of pumpkin seed oil and its physical-chemical properties. Nongye Gongcheng Xuebao (Beijing) 2011; 27: 383-7.

[25] Wang Q, Zhang L, Ji H, Yan H. Study on aqueous enzymatic extraction of pumpkin seed oil. Cereals and Oils 2011; 8: 21-3.

[26] Qi Q. Study on extraction of pumpkin seed oil by aqueous enzymatic method. Journal of Anhui Agriculture Science 2012; 40: 7410-3.

[27] Teixeira CB, Macedo GA, Macedo JA, da Silva LH, da C Rodrigues AM. Simultaneous extraction of oil and antioxidant compounds from oil palm fruit (Elaeis guineensis) by an aqueous enzymatic process. Bioresour Technol 2013; 129: 575-81.

[http://dx.doi.org/10.1016/j.biortech.2012.11.057] [PMID: 23274221]

[28] Kumar SPJ, Prasad SR, Banerjee R, Agarwal DK, Kulkarni KS, Ramesh KV. Green solvents and technologies for oil extraction from oilseeds. Chem Cent J 2017; 11: 9.

[http://dx.doi.org/10.1186/s13065-017-0238-8] [PMID: 28123451]

[29] Yusoff MM, Gordon MH, Ezeh O, Niranjan K. High pressure pretreatment of Moringa oleifera seed kernels prior to aqueous enzymatic oil extraction. Innov Food Sci Emerg Technol 2017; 39: 129-36. [http://dx.doi.org/10.1016/j.ifset.2016.11.014]

[30] Bligh EG, Dyer WJ. A rapid method of total lipid extraction and purification. Can J Biochem Physiol 1959; 37(8): 911-7. [http://dx.doi.org/10.1139/o59-099] [PMID: 13671378]

[31] Rodriguez-Amaya DB. A guide to carotenoid analysis in foods. Washington, DC: Ilsi Press, International Life Sciences Institute 2001; p. 37.

[32] Singleton VL, Rossi JA. Colorimetry of total phenolics with phosphomolybdic- phosphotungstic acid reagents. Am J Enol Vitic 1965; 16: 144-68.

[33] Rufino MSM, Alves RE, Brito ES, et al. Metodologia científica: Determinação da atividade antioxidante total em frutas pela captura do radical livre ABTS, Comunicado Técnico 128. Fortaleza, CE: Embrapa 2007; pp. 1-4.
[34] Santos RD, Ferrari RA. Extração aquosa enzimática de óleo de soja. Food Sci Technol (Campinas) 2005; 25(1): 132-8

[http://dx.doi.org/10.1590/S0101-20612005000100022]

[35] Gai Q, Jiao J, Mu P, et al. Microwave-assisted aqueous enzymatic extraction of oil from Isatis indigotica seeds and its evaluation of physicochemical properties, fatty acid compositions and antioxidant activities. Ind Crops Prod 2013; 45: 303-11.

[http://dx.doi.org/10.1016/j.indcrop.2012.12.050]

[36] Yang JY, Peng B, Wang M, Zou XG, Yin YL, Deng ZY. Characteristics and emulsifying properties of two protein fractions derived from the emulsion formed during aqueous extraction of Camellia oil. Food Hydrocoll 2019; 87: 644-52. [http://dx.doi.org/10.1016/j.foodhyd.2018.08.043]

[37] Wu J, Johnson LA, Jung S. Demulsification of oil-rich emulsion from enzyme-assisted aqueous extraction of extruded soybean flakes. Bioresour Technol 2009; 100(2): 527-33.

[http://dx.doi.org/10.1016/j.biortech.2008.05.057] [PMID: 18703331]

[38] Latif S, Anwar F. Effect of aqueous enzymatic processes on sunflower oil quality. J Am Oil Chem Soc 2009; 86: 393-400.

[http://dx.doi.org/10.1007/s11746-009-1357-8]

[39] Libo W, Yaqin X, Yu Y, Xin S. Aqueous enzymatic extraction of pumpkin seed oil and its physical-chemical properties. Nongye Gongcheng Xuebao (Beijing) 2011; 27(10): 383-7.

[40] Liu J, Gasmalla MAA, Li P, Yang R. Enzyme-assisted extraction processing from oilseeds: Principle, processing and application. Innov Food Sci Emerg Technol 2016; 35: 184-93.

[http://dx.doi.org/10.1016/j.ifset.2016.05.002]

[41] Liu S, Jiang L, Li Y. Research of aqueous enzymatic extraction of watermelon seed Oil of ultrasonic pretreatment assisted. Procedia Eng 2011; 15: 4949-55.

[http://dx.doi.org/10.1016/j.proeng.2011.08.921]

[42] de Rosso VV, Mercadante AZ. Identification and quantification of carotenoids, by HPLC-PDA-MS/MS, from Amazonian fruits. J Agric Food Chem 2007; 55(13): 5062-72.

[http://dx.doi.org/10.1021/jf0705421] [PMID: 17530774]

[43] Ribeiro BD, Coelho MAZ, Barreto DW. Production of concentrated natural beta-carotene from buriti (Mauritia vinifera) oil by enzymatic hydrolysis. Food Bioprod Process 2012; 90: 141-7. [http://dx.doi.org/10.1016/j.fbp.2011.02.003]

[44] Silva SM, Sampaio KA, Taham T, Rocco SA, Ceriani R, Meirelles AJA. Characterization of oil extracted from buriti fruit (Mauritia flexuosa) grown in the brazilian amazon region. J Am Oil Chem Soc 2009; 86: 611-6.

[http://dx.doi.org/10.1007/s11746-009-1400-9]

[45] Ferreira BS, de Almeida CG, Faza LP, et al. Comparative properties of Amazonian oils obtained by different extraction methods. Molecules 2011; 16(7): 5875-85.

[http://dx.doi.org/10.3390/molecules16075875] [PMID: 21750480]

[46] Ribeiro JC. Avaliação do potencial mutagênico e antimutagênico da polpa de açaí (Euterpe olereacea Mart) e do óleo de buriti (Maurita flexuosa) in vivo Tese de Doutorado. Ribeirão Preto, SP: Faculdade de Ciências Famacêuticas 2010.

[47] Luzia DMM. Propriedades funcionais de óleos extraídos de sementes de frutos do cerrado brasileiro Tese de doutorado. São José do Rio Preto, SP: Universidade Estadual Paulista, Instituto de Biociências, Letras e Ciências Exatas 2012.

\section{(C) 2019 Silva et al.}

This is an open access article distributed under the terms of the Creative Commons Attribution 4.0 International Public License (CC-BY 4.0), a copy of which is available at: (https://creativecommons.org/licenses/by/4.0/legalcode). This license permits unrestricted use, distribution, and reproduction in any medium, provided the original author and source are credited. 